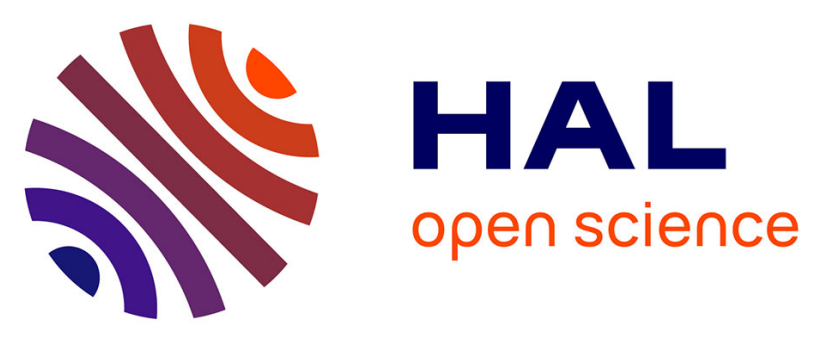

\title{
Evaluation of Ratio-Based Vegetation Indices For Annual Crops' Biomass Estimation. Lebna Watershed, Capbon, Tunisia
}

Itidel Alaya, Rim Zitouna, I. Mekki, Frédéric Jacob

\section{- To cite this version:}

Itidel Alaya, Rim Zitouna, I. Mekki, Frédéric Jacob. Evaluation of Ratio-Based Vegetation Indices For Annual Crops' Biomass Estimation. Lebna Watershed, Capbon, Tunisia. 2020 Mediterranean and Middle-East Geoscience and Remote Sensing Symposium (M2GARSS), Institute of Electrical and Electronics Engineers; Geoscience and Remote Sensing Society, Mar 2020, Tunis, Tunisia. pp.326-329, 10.1109/M2GARSS47143.2020.9105153 . hal-02891735

\section{HAL Id: hal-02891735 \\ https://hal.inrae.fr/hal-02891735}

Submitted on 15 Nov 2021

HAL is a multi-disciplinary open access archive for the deposit and dissemination of scientific research documents, whether they are published or not. The documents may come from teaching and research institutions in France or abroad, or from public or private research centers.
L'archive ouverte pluridisciplinaire HAL, est destinée au dépôt et à la diffusion de documents scientifiques de niveau recherche, publiés ou non, émanant des établissements d'enseignement et de recherche français ou étrangers, des laboratoires publics ou privés. 


\title{
EVALUATION OF RATIO-BASED VEGETATION INDICES FOR ANNUAL CROPS' BIOMASS ESTIMATION. LEBNA WATERSHED, CAPBON, TUNISIA \\ Alaya $^{1}$ I., Zitouna-Chebbi ${ }^{1}$ R, Mekki ${ }^{1}$ I, $\operatorname{Jacob}^{2}$ F \\ ${ }^{1}$ INRGREF, B.P. 10, 2080 Ariana, Tunisia \\ ${ }^{2}$ IRD/UMR LISAH, Montpellier, France
}

\begin{abstract}
The sustainabilityof agricultural sector involves a wise water resources management and therefore an accurate spatiotemporal vegetation monitoring with relevant tools such as satellite-derived indices (VI). In this study we evaluate the performance of NDVI and NDWI indices to infer the annual crops' (mainly wheat and faba-bean) aboveground biomass(AGB)at a Mediterranean watershed. The temporal evolution of IV over the annual crops' area shows the presence of low-density and low water content vegetation in early and late season. Areas with well-developed canopy and high plant water content are dominant in the mid-season. The observed AGB of wheat and faba-bean shows a good correlation with NDVI and NDWI values $\left(\mathrm{R}^{2}>0.71\right)$. The used vegetation indices represent a practical tool to determine the spatiotemporal variation of annual crops' AGB in Lebna watershed, however, a large dataset for validation is needed.
\end{abstract}

Index Terms: vegetation indices, NDVI, NDWI, annual crops, aboveground biomass.

\section{INTRODUCTION}

With the steady effects of climate change on the Mediterranean basin, the sustainability of agriculture in the region encounters many challenges related to the water resourcesand the crop productivity. In Tunisia where the agriculture is mainly based on rainfed annual crops, water scarcity and inter-annual variability represent already a crucial threat.Therefore, wise water resources management becomes a fundamental for sustainable agricultural sector, which requires an accurate monitoring of the vegetation conditions. Field measurements of crop biomass typically involvetime-intensive sample collection and repeated destructive sampling of vegetation. Currently, satellite- derived vegetation indices data offer a valuable tool for the characterization of canopy biophysical variables to support agricultural field management and decision-making[1][2]. In this context, we investigate the efficiency of two vegetation indices, namely the normalized difference vegetation index (NDVI) and the normalized difference water index (NDWI) to infer the annual crops' biomass in a rainfed landscape.The aim was to model the relationships between NDVI, NDWI and field measurements of AGB. For this purpose, Sentinel-2A products were used to extract NDVI and NDWI indices. The NDVI index that assesses the photosynthetic activity is considered in this study due to its robustness as indicator of vegetation status, spatial density distribution and phenology. The NDWI is used to infer the vegetation water content. This index is more sensitive than the NDVI to the vegetation growth especially at high canopy cover.

\section{MATERIALS AND METHODS}

\subsection{Study area}

The study was conducted at the Lebna watershed $\left(36^{\circ} 43^{\prime} \mathrm{N}-36^{\circ} 53^{\prime} \mathrm{N} ; 10^{\circ} 45^{\prime} \mathrm{E}-10^{\circ} 58^{\prime} \mathrm{E}\right)$ covering about $210 \mathrm{~km}^{2}$ in the Cap Bon Peninsula in northeast of Tunisia. The climate regime is at the 
boundary between subhumid and semiarid [3]. From downstream to upstream, the meanannual rainfall and the mean annual evapotranspiration (PenmanMonteith reference crop) range from $450 \mathrm{~mm}$ to $800 \mathrm{~mm}$ and from 1000 to $1500 \mathrm{~mm}$, respectively [3][4]. The soil of the study area represents a wide variety of parent material, texture, depth and fertility. Arable land covers $57 \%$ of the area with dominance of annual crops;annual crop (mainly wheat, fodder crops and legumes and spices) areas spread over $49 \%$ of the watershed and perennial crops (mainlyolive trees) cover $8 \%$ of the total area of the watershed [5].

\subsection{Data Collection and Analysis}

The study was conducted during 2016-2017 and 2018-2019 cropping cycles. In 2016-2017, the AGB sampling was carried out on five cultivated fields (four plots of wheat and one plot of faba-bean). During 2018-2019 season, six cultivated fields were considered (five fields of wheat and one of faba-bean). The fresh matter weight of $1 \mathrm{~m}^{2}$ sample were measured in the field for different stages of the growing season. The number of samples collected varied among the two years and for the two different crop types. For each plot (P1 to P6), the hemispherical photography werealso performed. The collected Sentinel-2A data comprise six images for 2016-2017 growing season and four images during the 2018-2019 cropping season. The observed data of fresh biomass were linearly interpolated to cover all the survey period with a daily step in order to determine their values during the Sentinel-2 passages. The resulting values were then compared with NDVI and NDWI mean values for each plot. The $\mathrm{R}^{2}$ and the root mean square error prediction (RMSE) were used to evaluate the accuracy of the models. The vegetation indices NDVI and NDWI were calculated from the Sentinel-2A bands covering Lebna watershed via R software. The NDVI defined as the normalized reflectance ratio of the near-infrared (NIR) and visible (RED) wavelengths

is determined from the bands $\mathrm{B} 4$ and $\mathrm{B} 8 \mathrm{~A}$ (eq 1).

$\mathrm{NDVI}=\mathrm{B} 8 \mathrm{~A}-\mathrm{B} 4) / \mathrm{B} 8 \mathrm{~A}+\mathrm{B} 4)$ eq 1

NDWI is calculated as the normalized reflectance ratio of the near-infrared and short wave infrared (SWIR) wavelengths from B8A and B11 bands (eq 2).

$\mathrm{NDWI}=(\mathrm{B} 8 \mathrm{~A}-\mathrm{B} 11) /(\mathrm{B} 8 \mathrm{~A}+\mathrm{B} 11) \quad$ eq 2

\section{RESULTS AND DISCUSSION}

The total rainfall data of the studied cropping seasons (September to May) varied from 400 $\mathrm{mm}$ for the 2016-2017 cycle to $480 \mathrm{~mm}$ for the 2018-2019 cycle. We observed an equal distribution between autumn and winter and around $4 \%$ of rainfall recorded during the spring of 2016-2017. A decreasing rainfall regime was observed form autumn to spring of 2018-2019: $43 \%, 35 \%$ and $22 \%$ for autumn, winter and spring respectively.

\subsection{Aboveground Biomass monitoring}

The temporal evolution of the $\mathrm{ABG}$ varied among the two years and for the two different crop types (Figure 1).

The vegetation survey during 2016-2017 growing season occurred during a dry period, which leads to the fluctuation of the observed fresh biomass in a short monitoring duration. For wheat crop the standard deviation of the AGB varies between 3 and 8 ton/ha with moderate 
inter-plots variability (variation coefficient $\mathrm{CV}$ between 12 and 21\%). During the 2018-2019 growing season, the observed ABG was in gradual increase to reach the maximum during the heading stages for wheat and the beginning of maturity for faba-bean (Figure 1). Monitored plots represent different vegetation stages that result in a high biomass variability between fields ( $\mathrm{CV}$ reaches 47\%). For wheat crops, the P1 plot is earlier but shows a great spatial variability. All the wheat plots reach maturity between late May and early June.

\subsection{Vegetation Indices of the annual crops' area}

The evolution of IV over the cropping seasons shows the presence of low-density vegetation (NDVI between 0.2 and 0.4) and well- developed canopy (NDVI that exceeds 0.4) at the start of the season (November-December). The frequency of high NDVI values raises in the mid-season (February-March) with the development of the canopy cover then it decreases again in mid-May with crops senescence. The variation of NDWI values frequency shows a low vegetation water content in early (December) and late season (May). Areas with high plant water content are dominant in the mid-season.

\subsection{Vegetation Indices-AGB relationship}

The comparison of the fresh AGB and NDVI valuesfor wheat plots illustrates a good correlation but with a high RMSE value (Figure 2.a). For faba-bean, the correlation is more significant with a low RMSE (Figure 2.b). However, this could be related to the low number of observations (5 observations) compared to the wheat dataset (22 observations). Similarly, the AGB shows a goodcorrelation with NDWI for wheat (Figure 3.a) and a significant relationship for faba-bean (Figure 3.b) but with higher RMSE values. We suspect this could be caused by the differences in crop type characteristics and between the sites. The variance associated with spatial and temporal differences in the ABG in these areas could be also associated to the spectral readings differentiating between live plants and dead material and moist soils.

The observed biomass of wheat and faba-bean shows a strong correlation with NDVI values (NDWI values respectively). However, an overestimation and anderestimation of crop biomass were detected at initial and later growth stages, which was particularly pronounced with the wheat crops. The results of this study suggest that, the spectral vegetation indices NDVI and NDWI represent a practical tool to determine the spatiotemporal variation of annual crops' biomass in Lebna watershed. However, the validation of these results might need the use of a larger dataset with more observations covering all the growth development season of the cropsand the combination of sensors that may compensate the deficiencies and improve the NDVI prediction performance.

\section{References}

[1] Rozensteina O., Haymanna N., Kaplana G. and Tannyab J. Estimating cotton water consumption using a time series of Sentinel-2 imagery. Agricultural Water Management 2018, 207; doi: 10.1016/j.agwat.2018.05.017. [2] Serrano J., Shahidian S. and da Silva J.-M., 2019. Evaluation of Normalized Difference Water Index as a Tool for Monitoring Pasture Seasonal and Inter-Annual Variability in a Mediterranean Agro-Silvo-Pastoral System. Water, 11, 62; doi: 10.3390/w11010062.

[3] IAO, 2002. Land Resources of the Oued Lebna Catchment (Tunisia). 20th CourseProfessional Master: Remote Sensing and Natural Resources Evaluation. Istituto Agronomico per l'Oltremare, Florence, Italie

$132 \mathrm{p}$.

[4] Zitouna-Chebbi R., Prévot L., JacobF., Mougou R., Voltz M., 2012. Assessing theconsistency of eddy covariance measurements under conditions of sloping topographywithin a hilly agricultural 
catchment.

Agric.

For.

Meteorol.

164 ,

$123-$

135.

[5] Mekki I. Bailly J.S., Jacob F., Chebbi H., Ajmi T., Blanca Y., Zairi, A., Biarnès A., 2018. Impact of farmland fragmentation on rainfed crop allocation in Mediterranean landscapes: A case study of the Lebna watershed in Cap Bon, Tunisia. Land Use Policy, 75, 772783.

Figure 1. Temporal variation of fresh biomass during"2018/2019" season
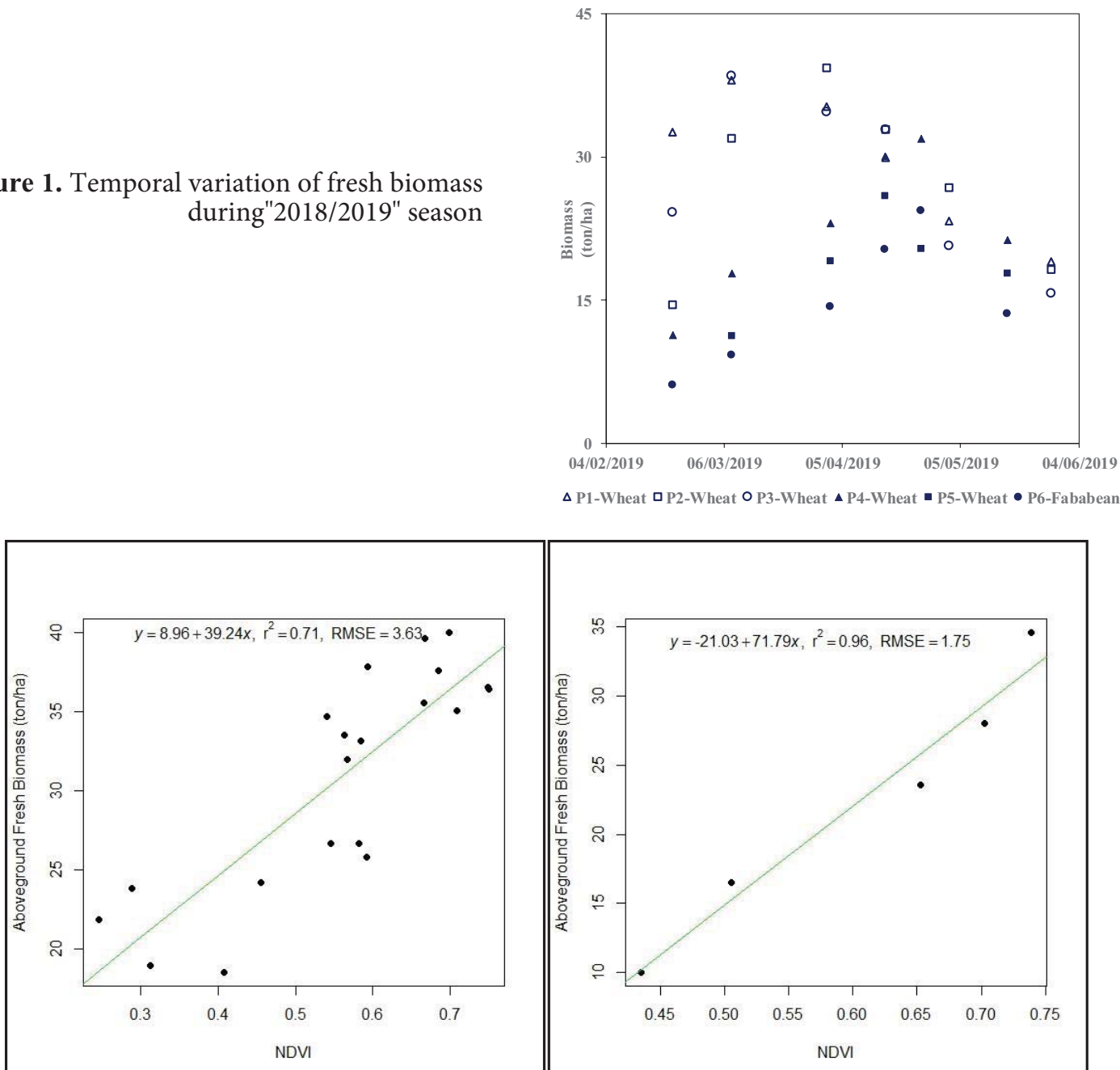

Figure 2. Variation of the aboveground fresh biomass of wheat (a) and faba-bean (b) according to NDVI values

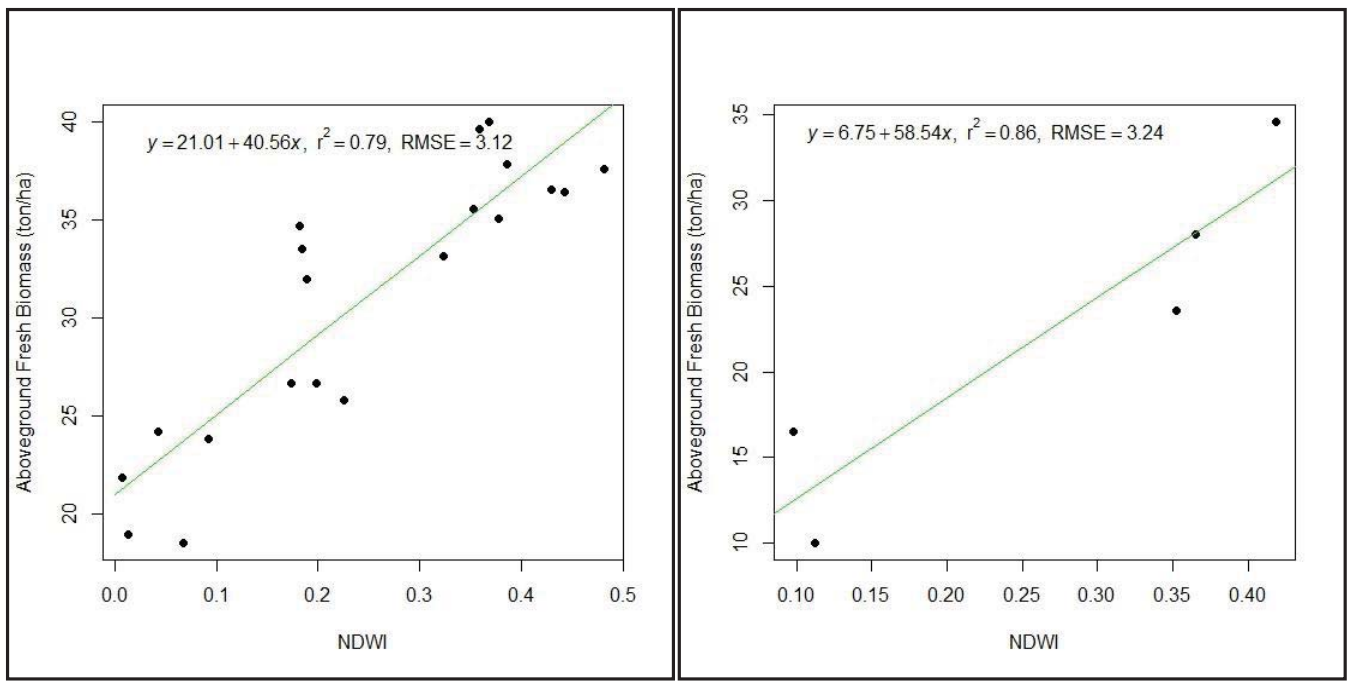

Figure 3. Variation of the aboveground fresh biomass of wheat (a) and faba-bean (b) according to NDWI values 